\title{
Direct Medical Cost Analysis Among Coronary Heart Disease and Heart Failure Outpatients at One Hospital
}

\author{
Nunik Dewi Kumalasari ${ }^{1}$, Abdul Rahem², Bobby Presley ${ }^{3,4}$, Eko Setiawan ${ }^{3,4^{*}}$ \\ 1. Program Studi Magister IImu Farmasi Universitas Surabaya, Surabaya, IndonesiaFakultas Farmasi Universitas \\ Gadjah Mada, Yogyakarta \\ 2. Fakultas Farmasi, Universitas Airlangga, Surabaya \\ 3. Departemen Farmasi Klinis dan Komunitas, Fakultas Farmasi, Universitas Surabaya, Surabaya \\ 4. Pusat Informasi Obat dan Layanan Kefarmasian (PIOLK), Fakultas Farmasi, Universitas Surabaya, Surabaya \\ Submitted: 17-08-2018 Revised: 11-12-2018 Accepted: 20-06-2019 \\ Korespondensi : Eko Setiawan : Email : ekosetiawan.apt@gmail.com
}

\begin{abstract}
Long-term treatment of cardiovascular disease may give impact in a high burden of medical cost for the patient. A concern arises whether the health budget allocation prepared by the Indonesian Government through "Jaminan Kesehatan Nasional" program is enough to cover medical cost for the outpatient treatment. This study aims to calculate the direct medical cost of patients with coronary heart disease and heart failure and compare it with the Indonesian Case Base Groups (INA-CBGs) tariff. This is a prospective and observational study carried out in one of the public hospitals in East Java between February and April 2015. All data related to outpatients with coronary heart disease and heart failure were analyzed. Direct medical cost analysis in this study calculated from a combination of cost of medication, health professional services, electrocardiography, emergency care services, and laboratory test component, then it was compared with INA-CBGs tariff from ICD 10. Total of 390 patients included were 387 patients with coronary heart disease (99.23\%) and three (3) patients with heart failure $(0.77 \%)$. Average direct medical cost for patients with coronary heart disease and heart failure were IDR 130.593,6 (range IDR 50.282 - IDR 385.911) and IDR 128.587 (range IDR 112.832 - IDR 140.103), respectively. Even though this study showed that budget allocation of INA-CBGs could cover the average direct medical cost of patients with both of diseases, some patients had a direct medical cost higher than the limit of INACBGs allocation. Therefore, an optimal interprofessional collaboration between physician and pharmacist needed to provide medical treatment based on patient needs and keep it within budget allocation range. Keywords: coronary heart disease, heart failure, direct medical cost.
\end{abstract}

\section{INTRODUCTION}

The burden of medical cost that needed in health system for patient with coronary heart disease is enormous ${ }^{1-4}$. Analysis related to the bill that patient with coronary heart disease and heart failure should pay was carried out in China and Korea, and the result is about US\$ 17 million and US\$2.52 trillion in a row ${ }^{1,2}$. Direct medical cost is a biggest component in the analysis that carried out in both countries ${ }^{1,2}$. In detail, the burden of indirect cost that must be borne by Korean government related to coronary heart problem are as follows: Economic burden due to productivity loss; 33,6\%, transportation $(8,1 \%)$, and informal caregiver cost; $4.9 \%)^{2}$. The burden of country's medical cost for heart failure patients are not cheap. The result of medical cost analysis that conducted in 197 countries show that the total amount of money those countries need to pay for heart failure case is US\$ 108 trillion per year. Around 60\% of it is used for direct medical cost ${ }^{3}$. The result of a recently published systematic study shows the amount of money that must be incurred in dealing with heart failure cases is around \$908-\$84.434 per patient/year4. Medical cost will increase as the patient condition is getting worse ${ }^{4}$. Therefore, there should be a preventive action to minimize the deterioration of patient's condition as an attempt to control the swelling of medical cost of a country.

In a relatively stable condition, coronary heart disease and heart failure patients will get outpatient healthcare service. There are two main goals of giving drug therapy to a patient 
with coronary heart disease, that is: to eliminate the pain when an attack occurs and to prevent the attacks from happening again ${ }^{5}$. In an effort to achieve the second goal, there are several things that must be controlled, those things are: reduce the thickening of plaque that clog the blood vessels, maintain the stability of heart plaque so it does not break, and prevent a thrombosis to occur ${ }^{5}$. Nitrate categorized drug, beta receptor blockers ( $\beta$-blockers), and calcium channel blockers are drugs that recommended when heart attack occurs, while antiplatelet drugs, lipid-lowering agents, and renin-angiotensinaldosterone system blockers (RAAS) is a drugs that must be given to prevent repeated attacks and death ${ }^{5}$. Therapy for heart failure patients is aimed to improve clinical conditions, capacity to carry out activities, and the life quality of patients and preventing the need for hospitalization and death 7 . Some first-line therapies that are recommended for improving the function of the heart and blood vessel systems will be given to patients, including the blockers class angiotensinconverting enzyme (ACE) and beta receptor blockers ( $\beta$-blockers) for heart failure patients ${ }^{6,7}$. The choosing of main therapy above is adjusted by several factors and the most vital is the record of the myocardial infarction occurrence $^{7}$. In addition to these two drugs, heart failure patients also need to get statin drugs in an effort to prevent attacks and prolong life ${ }^{7}$. Diuretic drugs, especially loop diuretics, are generally also given to treat the patient's symptoms. The use of drugs in patients with coronary heart disease and heart failure is lifelong and continuous usage is needed. Results of some researches prove that the continuous usage of drugs in coronary heart disease and heart failure patients show signs of positive impact in clinical outcome of the patients and medical cost controlling 8,9 . Full-covered medical cost is one of the factors that give contribution to continuous usage of drugs in heart and blood vessel disorders ${ }^{10}$.
Indonesian government through their program called Jaminan Kesehatan Nasional (JKN), show a commitment to develop health insurance comprehensively for Indonesian citizen. Through the program, it is expected that health needs of Indonesian citizen and the continuous medication of coronary heart disease and heart failure patients are guaranteed. However, until now, it is not yet known whether the budget allocated by the government through the Badan Penyelenggara Jaminan Sosial (BPJS) has met the medical needs of patients with coronary heart disease and outpatient heart failure including the cost of doctors' consultation, laboratory examinations, and drugs. The lack of such information could cause inefficiency of healthcare service to coronary heart disease and heart failure patients, consist of: 1) Drugs only given for short period of time, 2) laboratory tests that are not carried out regularly and continuously. Insufficiency of drugs for long period of time causes outpatients to get the drugs in healthcare facilities more often and the consequence is those outpatients tend to disobey the continuous usage of drugs. Laboratory results, particularly the levels of low-densitylipoprotein (LDL), are needed as a consideration for adjusting the dosage of lipidlowering agent drug therapy. The lack of information related to LDL level causes patients to get same therapy dosage since their first therapy, and higher the chance that the dosage they get is lower than their actual needs.

Information regarding the adequacy of BPJS budget in providing healthcare service for coronary heart disease and heart failure outpatients is vital to be understood, considering the huge number of coronary heart disease and heart failure patients in Indonesia. ${ }^{11}$ Without this information, not only put the patients at high risk of getting insufficient healthcare service, but also could cause confusion in the hospital management 
in managing funds. Therefore, a research related to medical cost analysis, particularly in direct medical cost of coronary heart disease and heart failure outpatients needs to be done.

\section{Hospital setting Where Data is Taken}

The hospital where the data is taken is a type B hospital, consists of 202 beds. There is one doctor specialized for heart and blood vessels. The average outpatient visit is 300 patients/day. Medication for chronic disease participants in the hospital where the data is taken is served for one month with proportion: the need for medicine for seven (7) days is provided by the hospital with the costs included in the INA-CBGs rate and as much drug requirements for twenty three (23) days are served at a hospital pharmacy installation that works with BPJS healthcare with a cost outside the INA-CBGs bills ${ }^{12-14}$. Medication services for twenty three (23) days with costs from outside the INA-CBGs bills based on the provisions of the minister of health, namely additional prescription drug costs for chronic diseases (based on the National Formulary) are collectively billed through separate claims to Badan Penyelenggara Jaminan Sosial (BPJS) healthcare using Asterix Pelayanan Apotek software from PT Askes (Persero).

This study aims to calculate the direct medical cost of coronary heart patients and heart failure outpatients for seven (7) days medication needs compared to the Indonesian Case Base Groups (INA-CBGs) rates at a public hospital in East Java.

\section{METHODS}

This study was an observational study conducted prospectively during the months of February-April 2015 at the outpatients' polyclinic in a public hospital in the East Java province. All outpatient data with diagnosis of coronary heart disease and heart failure that meets the inclusion criteria will be taken to be involved in the process of further analysis. Patient inclusion criteria in this study were patients with a diagnosis of coronary heart disease and heart failure with complications and without complications who received the drug for 7 (seven) days and patients registered as BPJS Kesehatan participants. The research sampling process began after obtaining permission from Head of National and Political Unity Agency (Kepala Badan Kesatuan Bangsa dan Politik) (Letter Number 070/512 / 416-206 / 2015) and Hospital Director (Letter Number 423.4 / 1461 / 416-211 / 205).

The source of cost data in this study is patient billing data obtained from the Hospital management information system (sistem informasi manajemen/SIM), Pharmacy SIM, INA-CBGs data rates collected through databases from computers equipped with the 10th edition of International Classification of Diseases (ICD 10). Patient data contained in medical records of outpatients is used if needed. The following data are recorded for each patient who fulfills the inclusion criteria and is further analyzed: 1) patient characteristics (age, sex, and diagnosis); 2) drug characteristics (type and dosage of drug); medical expenses (drug costs, professional services, electrocardiography costs, service fees at the emergency department (instalasi gawat darurat/(GD), and laboratories).

The direct medical cost analysis is done by summing up the cost of medicines, professional services, electrocardiography costs, IGD fees and laboratories for the needs of 7 (seven) days contained in the billing. The perspective of health care providers (providers' perspective) was used in this study. After calculating the direct medical cost of coronary heart disease patients and heart failure from billing that represents the amount of the charge (charge), the value is converted into the real cost (real cost) charged by the hospital to patients. The conversion process is done by using a cost to charge ratio (CCR) obtained from published research. Analysis of direct medical cost data is compared with INA-CBGs rates based on the diagnosis of coronary heart disease and heart failure. If the direct medical cost is lower than the INACBGs rates, then the INA-CBGs rates are sufficient, and vice versa if the direct medical cost is higher in the INA-CBGs rates, then the INA-CBGs rates mean that they are not 
Table I. Characteristics of Heart Patients Outpatient

\begin{tabular}{llcc}
\hline & Characteristics & Number of Patients & Percentage (\%) \\
\hline Age group & $15-24$ & - & - \\
(year) & $25-34$ & 1 & 0.26 \\
& $35-44$ & 30 & 7.69 \\
& $45-54$ & 95 & 24.36 \\
& $55-64$ & 120 & 30.77 \\
& $65-74$ & 109 & 27.95 \\
\multirow{5}{*}{ Sex } & $75+$ & 35 & 8.97 \\
\multirow{5}{*}{ Diagnosis } & Male & 181 & 46.41 \\
& Female & 209 & 53.58 \\
& Heart Failure & 3 & 0.77 \\
& Coronary Heart Disease & 387 & 99.23 \\
\hline
\end{tabular}

Symbol: Percentage calculation is done by dividing the number of patients for certain characteristics by the total number of patients then multiplying by 100

sufficient. The process of adjusting costs using the inflation rate was not carried out in this study because the amount of direct medical costs and the rates of INA-CBGs were in the same year.

\section{RESULTS AND DISCUSSION}

A total of 390 patients' data was recorded and analyzed in this study. Information about the characteristics of heart patients which includes age group, sex and diagnosis (Table I). The amount of data from patients with a diagnosis of coronary heart disease was 387 people $(99.23 \%)$ and heart failure patients was 3 people $(0.77 \%)$. From a total of 387 patients with a diagnosis of coronary heart disease, there were 21 patients with a diagnosis of acute myocardial infarction and 366 people with a diagnosis of atherosclerotic heart disease. Most patients are female $(53.58 \%)$. The highest age prevalence was in the age group $55-64$ years $(30.77 \%)$. The average age of a heart patient is 60 years.

Drug class data in heart patients outpatient for the needs of 7 (seven) days (Table II). The drug class that is often used in heart patients outpatient for the needs of 7 (seven) days is the angiotensin II receptor antagonist $(19.46 \%)$. The average patient in this study received 3 (three) classes of drugs with a minimum of 1 (one) and a maximum of 7 (seven) classes of drugs.

Based on Table II, it can be seen that the drug angiotensin II receptor antagonist is given more to the patient than the class of angiotensin converting enzyme inhibitors. In this study, the background of the use of angiotensin II receptor antagonist was unknown. One of the advantages of the use of the angiotensin II receptor antagonist is that the risk of cough is relatively lower compared to the angiotensin converting enzyme inhibitor class ${ }^{15}$. This can be considered by doctors in choosing the angiotensin II receptor antagonist class. In addition to this, Win et al. (2015) found that the incidence of angioedema due to the use of angiotensin converting enzyme inhibitor class in Thai patients was more than that of angiotensin II receptor antagonist ${ }^{16}$. Pharmacovigilance studies related to the risk of angioedema due to the use of angiotensin II receptor antagonist and angiotensin converting enzyme inhibitor in the Indonesian patient population are needed to ensure the safety of the use of angiotensin II receptor antagonist and angiotensin converting enzyme inhibitor in Indonesia. Regardless of the considerations, it is important to note that the use of angiotensin converting enzyme inhibitor is more recommended in cases of heart failure than 
Eko Setiawan, et al

Table II. Drug Classes in Heart Patients Outpatient for The Needs of 7 (Seven) Days

\begin{tabular}{|c|c|c|c|}
\hline & Drug Classes & $\begin{array}{c}\text { Number of } \\
\text { Patients }\end{array}$ & $\begin{array}{c}\text { Percentage } \\
(\%)\end{array}$ \\
\hline \multirow{14}{*}{$\begin{array}{l}\text { Drugs for } \\
\text { chronic } \\
\text { disease }\end{array}$} & Angiotensin II receptor antagonist & 211 & 19.46 \\
\hline & Nitrate & 162 & 14.94 \\
\hline & Calcium antagonist & 134 & 12.36 \\
\hline & Beta blockers & 121 & 11.16 \\
\hline & Potassium-sparing diuretics & 71 & 6.54 \\
\hline & Strong diuretics & 58 & 5.35 \\
\hline & Angiotensin converting enzyme inhibitors & 52 & 4.79 \\
\hline & Antiplatelet & 41 & 3.78 \\
\hline & Cardiac glycosides & 40 & 3.69 \\
\hline & Antiarrhythmias & 11 & 1.01 \\
\hline & Xanthine oxidase inhibitors & 11 & 1.01 \\
\hline & Statins & 9 & 0.83 \\
\hline & Sulfonilurea & 5 & 0.46 \\
\hline & Biguanida & 2 & 0.18 \\
\hline \multirow{29}{*}{$\begin{array}{c}\text { Drugs for } \\
\text { symptomatic } \\
\text { disease }\end{array}$} & Vitamin & 31 & 2.86 \\
\hline & Proton pump inhibitors & 22 & 2.03 \\
\hline & Non-steroidal anti-inflammatory & 14 & 1.29 \\
\hline & Supplement & 11 & 1.01 \\
\hline & Benzodiazepines & 10 & 0.92 \\
\hline & Opiates & 9 & 0.83 \\
\hline & Antihistamines & 9 & 0.83 \\
\hline & Mucolytic & 8 & 0.74 \\
\hline & Antagonist $\mathrm{H} 2$ & 7 & 0.64 \\
\hline & Antacids & 5 & 0.46 \\
\hline & Cephalosporin & 4 & 0.37 \\
\hline & Expectorant & 3 & 0.27 \\
\hline & Sucralfat & 3 & 0.27 \\
\hline & Xanthine bronchodilator & 3 & 0.27 \\
\hline & Histamine analoque & 2 & 0.18 \\
\hline & Corticosteroids & 2 & 0.18 \\
\hline & Anti-tuberculosis & 2 & 0.18 \\
\hline & Antiseptic & 1 & 0.09 \\
\hline & Antithyroid & 1 & 0.09 \\
\hline & Tricyclic antidepressants & 1 & 0.09 \\
\hline & Penicillin & 1 & 0.09 \\
\hline & Macrolide & 1 & 0.09 \\
\hline & Quinolone & 1 & 0.09 \\
\hline & Rifampicin & 1 & 0.09 \\
\hline & Antispasmodics & 1 & 0.09 \\
\hline & Alpha adrenergic blockers & 1 & 0.09 \\
\hline & Serotonin antagonist $5 \mathrm{H} 3$ & 1 & 0.09 \\
\hline & Antipyretic analgesics & 1 & 0.09 \\
\hline & Total & 1084 & 100 \\
\hline
\end{tabular}


the angiotensin II receptor antagonist class ${ }^{7}$. The recommendations are based on five research evidence (published between 19871999) which stated that the use of a class of angiotensin converting enzyme inhibitor in heart failure patients, especially with a decrease in ejection fraction, reduces the risk of death ${ }^{7}$. Heart failure patients in this study, namely as many as three patients, received II receptor antihypertensive antagonists' therapy. A systematic study and meta-analysis of 22 randomized controlled studies revealed that there was no significant difference between heart failure patients who received a class of angiotensin converting enzyme inhibitor and angiotensin II receptor antagonist in reducing the risk of death, hospitalization, myocardial hospitalization. Infarction, and stroke ${ }^{17}$. Thus, the use of the angiotensin II receptor antagonist can be used in patients with chronic heart failure who have a history of unwanted drug reactions when using a class of angiotensin converting enzyme inhibitor.

Not all patients in this study received antiplatelet drug class. The provision of antiplatelet to coronary heart patients is an attempt to prevent thrombosis which could occur at any time due to a rupture of the plaque in blood vessels ${ }^{18}$. The medical history or comorbidities of gastrointestinal bleeding can be the reason to not give antiplatelet, especially aspirin, to patients ${ }^{19}$. The risk of upper gastrointestinal bleeding can still occur if aspirin is used chronically even at low doses (RR 2.3; 95\% CI 2.0-2.6) ${ }^{19}$. However, these risks are not greater compared to the benefits produced after antiplatelet administration ${ }^{5-7}$. Concerns about bleeding can be anticipated with the use of drugs with proton-pump inhibitors ${ }^{18,19}$. In a meta-analysis, Tran-Duy et al. (2015) prove that the provision of proton pump inhibitors can reduce the risk of gastrointestinal bleeding by $50 \%$ (RR $0.5 ; 95 \%$ CI $0.32-0.80)^{20}$.

Aside from antiplatelet, lipid-lowering agents, in this research statins were not given to all patients. The provision of statin is not only intended to reduce low-density lipoprotein (LDL) but also to produce pleiotropic effects, namely stabilization of the plaque and prevent rupture of the blockage that can trigger thrombosis ${ }^{21-24}$. Positive impact of statin prevention on the occurrence of attacks Repeat heart is also evident in patients with LDL levels that have reached the therapeutic target even less than the target of therapy ${ }^{25}$. Thus, the provision of statins must continue to be given to patients regardless of the LDL value the patient has ${ }^{5-7}$.

Collaborative research between pharmacists and doctors conducted prospectively needs to be done to see the accuracy of antiplatelet use and lipid lowering agents in patients with heart problems. Through this research, the pharmacist can confirm to the doctor to identify the reasons for not giving a class of drugs to the patient and discuss the best alternative solutions to achieve a good patient clinical outcome.

The total direct medical cost for all patients in this study for treatment needs for seven (7) days is Rp.50,925,420. Details of costs for all patients (Table III). Drug costs provide the largest distribution of Rp.24,095,690 $(47.31 \%)$ of the total direct medical costs. Schlatter et al. $(2017)^{26}$ conducted to patients with ischemic heart disease and research conducted by Ogah et al., (2014) $)^{27}$ on heart failure patients with outpatient settings stated that the cost of drugs as the largest direct medical cost financing component was also found in this study. The amount of the health budget that must be spent on the components of the drug needs attention from various parties, especially hospitals and BPJS, taking into account the budgetary trends for drugs which tend to increase ${ }^{28}$. Some of the factors that led to the increase include: price changes due to inflation, volume increased use, increase in population, especially elderly, and use of non-generic drugs ${ }^{29}$. Strategies to control the rate of increase in drug use costs should be sought by applying a combination of interventions not only to health workers, especially doctors but also to patients as consumers and drug manufacturers as drug supplier $^{30}$. 
Table III. Total Direct Medical Cost for All Heart Patients Outpatient

\begin{tabular}{ccc}
\hline Component & Total Costs in 2015 (Rp) & $\begin{array}{c}\text { Percentage of Total 2015 Costs } \\
(\mathbf{\%})\end{array}$ \\
\hline Drug Costs & $24,095,690$ & 47.31 \\
Professional Services & $14,465,000$ & 28.40 \\
EKG $^{\mathrm{a}}$ Costs & $11,640,000$ & 22.85 \\
Laboratory Costs, Radiology & 660,000 & 1.29 \\
IGD Costs & 64,730 & 0.12 \\
Direct Medical Cost & $\mathbf{5 0 , 9 2 5 , 4 2 0}$ & $\mathbf{1 0 0}$ \\
\hline
\end{tabular}

Remarks Table III: a388 patients received an electrocardiography (ECG) examination; bSeven (7) patients received laboratory and radiological examinations; 'One (1) person through the IGD

Table IV. Average Direct Medical Cost Details for Each Patient

\begin{tabular}{ccc}
\hline Component & Average Costs (Rp) & Cost Range (Rp) \\
\hline Drug Costs & $61,783.82$ & $2,415.0-161,524.0$ \\
Professional Services & $37,089.74$ & $25,000.0-60,000.0$ \\
EKGa Costs & $30,000.00$ & - \\
Laboratory Costs, Radiology & $94,285.71$ & $30,500,-170,000.0$ \\
\hline
\end{tabular}

Table information IV: aCosts set by the hospital

The average per-patient cost detail (Table IV), while the direct medical cost per patient based on diagnosis (Table V). Based on Table IV, the average cost of drug use in patients with a diagnosis of coronary heart and heart failure is the highest compared to other direct medical cost components. However, the cost of the drug is not entirely indicative of heart and blood vessel disease (Table II). It is very likely that patients with major problems with heart problems have other comorbidities that are not always chronic diseases. Seeing the potential for drug provision for other health problems, especially those that are symptomatic, cooperation and communication between doctors and pharmacists is needed to determine the best treatment for patients without exceeding the budget limit set by the BPJS. In this research, the upper limit of the range of $d$ rug costs given to patients was Rp.161,254.0, which meant that it had spent $97.49 \%$ of the BPJS budget.

LDL levels were not examined in all patients in this study by noting that only seven
(7) of the total 390 patients received laboratory tests. LDL levels should be examined as much as possible in patients with periodic and continuous impaired cardiac function because the plaque process and is strongly influenced by LDL levels ${ }^{31}$. Increased costs are one consequence of the need to examine LDL levels in patients with impaired heart function. Therefore, further studies need to be done regarding the frequency of LDL level examinations most ideally implemented in Indonesia.

In addition to producing some important information related to financing the health of outpatients with impaired cardiac function, this study has a number of limitations. First, the results of this research do not describe the magnitude of the direct medical cost burden of heart care patients in a health institution for a whole period of the budgetary budget. Second, the direct medical cost burden in this study, both in total and per-patient average, does not reflect the magnitude of the burden on private health institutions. Differences in drug prescribing 
Table V. Average Direct Medical Cost for Each Patient Based on Diagnosis

\begin{tabular}{ccccc}
\hline \multicolumn{1}{c}{ Diagnosis } & $\begin{array}{c}\text { Number of } \\
\text { patients }\end{array}$ & $\begin{array}{c}\text { Average } \\
\text { Costs (Rp) }\end{array}$ & $\begin{array}{c}\text { Cost Range } \\
\text { (Rp) }\end{array}$ & $\begin{array}{c}\text { BPJS Budget } \\
\text { (Rp) }\end{array}$ \\
\hline $\begin{array}{c}\text { Coronary heart disease } \\
\text { a. Atherosclerotic }\end{array}$ & 387 & $130,593.4$ & $50,282.0-385,911.0$ & \\
$\quad \begin{array}{l}\text { heart disease } \\
\text { b. } \quad \text { Myocard Infarc }\end{array}$ & 366 & $129,549.9$ & $50,282.0-385,911.0$ & $165,400.0^{\mathrm{a}}$ \\
& 21 & $148,779.1$ & $69,963.0-252,860.0$ & \\
Heart failure & 3 & $128,587.0$ & $112,832.0-140,103.0$ & $165,400.0^{\mathrm{b}}$ \\
\hline
\end{tabular}

Remarks Table V: aBudget allocation that can be billed using the INA-CBGs Z098 code (Followup examination after other treatment for other conditions) combined with I251 (Atherosclerotic heart disease) or I219 (Acute myocardial infarction, unspecified); ${ }^{b}$ Budget allocation that can be billed using the INA-CBGs Z098 code (Follow-up examination after other treatment for other conditions) combined with I500 (Congestive heart failure)

patterns can affect the difference in direct medical cost burden between public and private health institutions.

\section{CONCLUSION}

The budget allocated by BPJS for outpatients with a diagnosis of coronary heart and heart failure through INA-CBGs, in general, is sufficient for the patient's direct medical cost for seven (7) days of treatment. Further analysis shows that costs for drugs are the highest direct medical cost financing component compared to other components. Coordination between health workers in an effort to guarantee the quality of treatment and control the increase in costs related to drug use needs to be pursued by considering the possible use of drugs which consumes almost all of the fund allocation.

\section{FUNDING}

This research is not funded by any grant source.

\section{CONTENT OF INTEREST}

The researcher stated that there was no conflict of interest in this study.

\section{REFERENCES}

1. Le C., Fang Y., Linxiong W., Shulan Z., Golden AR. Economic burden and cost determinants of coronary heart disease in rural southwest China: a multilevel analysis. Public Health. 2015 Jan;129(1):68-73.

2. Chang HS., Kim HJ., Nam CM., Lim SJ., Jang $\mathrm{YH}, \mathrm{Kim} \mathrm{S}$, et al. The socioeconomic burden of coronary heart disease in Korea. I Prev Med Public Health. 2012; 45(5):291-300.

3. Cook C., Cole G., Asaria P., Jabbour R., Francis DP. The annual global economic burden of heart failure. Int J Cardiol. 2014;171(3):368-76.

4. Shafie AA., Tan YP., Ng CH. Systematic review of economic burden of heart failure. Heart Fail Rev. 2018;23(1):131145.

5. Montalescot G., Sechtem U., Achenbach S., Andreoti F., Arden C., Budaj A., et al. 2013 ESC guidelines on the management of stable coronary artery disease. Eur Heart J. 2013;34:2494-3003.

6. Krum H., Driscoll A. Management of heart failure. Med $J$ Aust. 2013;199(5):334-339.

7. Ponikowski P., Voors AA, Anker SD., Bueno H., Cleland JGF., Coats AJS., et al., 2016 ESC guidelines for the diagnosis and treatment of acute and chronic heart failure. Eur Heart J. 2016;37:2129-2200.

8. Bitton A., Choudhry NK., Matlin OS., Swanton K., Shrank WH. The impact of medication adherence on coronary 
artery disease costs and outcomes: a systematic review. Am J Med. 2013;126(4):357.e7-357.e27.

9. Hood SR., Giazzon AJ., Seamon G., Lane KA., Wang J., Eckert GJ., et al., Pharmacotherapy. 2018;38(5):539-545.

10. Banerjee A., Khandelwal S., Nambiar L., Saxena M., Peck V., Moniruzzaman M., et al., Open Heart 2016;3:e000438.

11. Badan Penelitian dan Pengembangan KEsehatan-Kementerian KEsehatan Republik Indonesia. Riset Kesehatan Dasar (RISKESDAS) 2013. 2013 [cited 2015 Agustus]. Available from: http://www.depkes.go.id/resources/do wnload/

general/Hasil\%20Riskesdas\%202013.pd f.

12. Badan Penyelenggara Jaminan Sosial Kesehatan. Peraturan Badan Penyelenggara Jaminan Sosial Kesehatan no 1 tahun 2014. 2014 [cited 2015 Agustus]. Available from: https://www.google.com/search?source =hp\&ei= qaNzW9PpJsj6QbQva7wBQ\&q=Peraturan+Badan+Pe nyelenggara+Jaminan+

Sosial+Kesehatan+Nomor $+1+$ Tahun +20 14+tentang+Penyelenggaraan+Jaminan +Kesehtan\&oq=Peraturan+Badan+Peny elenggara+Jaminan+Sosial+Kesehatan+ Nomor+1+Tahun+2014+tentang+Penyel enggaraan+Jaminan+Kesehtan\&gs_l=ps yab.3...4401.4401.0.4711.2.1.0.0.0.0.0.0..0

.0.......1c.1.64.psy-ab..2.0.0.0 ...0.F_OdK9_fXKA

13. Menteri Kesehatan Republik Indonesia. Pelaksanaan pelayanan kesehatan bagi peserta BPJS kesehatan pada fasilitas kesehatan tingkat pertama dan fasilitas kesehatan tingkat lanjutan dalam penyelenggaraan program jaminan kesehatan. 2014 [cited 2015 Agustus]. Available from: http://www.jkn.kemkes.go.id/ attachment/unduhan/SE\%20ttg\%20Pela ksanaan\%20Pelayanan\%20Kesehatan\% 20Bagi\%20Peserta\%20BPJS\%20Kesehat an.pdf.
14. Badan Penyelenggara Jaminan Sosial Kesehatan. Panduan praktis program rujuk balik bagi peserta JKN. [cited 2015 Agustus]. Available from: https://bpjskesehatan.go.id/bpjs/dmdocuments/42 38e7d5f66ccef4ccd89883c46fcebc.pdf.

15. Caldeira D., David C., Sampaio C. Tolerability of angiotensin-receptor blockers in patients with intolerance to angiotensin-converting enzyme inhibitors: a systematic review and meta-analysis. Am J Cardiovasc Drugs. 2012;12(4):263-77.

16. Win TS., Chaiyakunapruk N., Suwankesawong W., Dilokthornsakul P., Nathisuwan S. Renin angiotensin system blockers-associated angioedema in the Thai population: analysis from Thai National Pharmacovigilance Database. Asian Pac J Allergy Immunol. 2015;33(3):227-35.

17. Heran BS., Musini VM., Bassett K., Taylor RS., Wright JM. Angiotensin receptor blockers for heart failure. Cochrane Database Syst Rev. 2012;(4):CD003040.

18. Gillette M., Morneau K., Hoang V., Virani S., Jneid H. Antiplatelet management for coronary heart disease: advances and challenges. Curr Atheroscler Rep. 2016;18:35.

19. García Rodríguez LA., Martín-Pérez M., Hennekens CH., Rothwell PM., Lanas A. Bleeding risk with long-term lowdose aspirin: a systematic review of observational studies. PLoS One. 2016;11(8):e0160046.

20. Tran-Duy A., Vanmolkot FH., Joore MA., Hoes AW., Stehouwer CD. Should patients prescribed long-term low-dose aspirin receive proton pump inhibitors? A systematic review and meta-analysis. Int J Clin Pract. 2015;69(10):1088-111.

21. Lim SY. Role of statins in coronary artery disease. Chonnam Med J. 2013;49(1): 1-6.

22. Szyguła-Jurkiewicz B., Szczurek W., Król B., Zembala M. The role of statins in chronic heart failure. Kardiochir 
Torakochirurgia Pol. 2014;11(3):301305.

23. Van der Hars.t, de Boer RA. Statins in the treatment of heart failure. Circ Heart Fail. 2010;3:462-464.

24. Gastelurrutia P., Lupón J., de Antonio M., Urrutia A., Díez C., Coll R., et al., Statins in heart failure: the paradox between large randomized clinical trials and real life. Mayo Clin Proc. 2012;87(6):555-560.

25. Kuwabara M., Kondo F., Hamada T., Takahashi JI., Takenaka N., Furuno T. Impact of statins therapy for ischemic heart disease patients with low-density lipoprotein cholesterol levels less than $100 \mathrm{mg} / \mathrm{dL}$. Acta Cardiol Sin. 2016;32(5):565-569.

26. Schlatter RP., Hirakata VN., Polancyk A. Estimating the direct costs of ischemic heart disease: evidence from a teaching hospital in Brazil, a retrospective cohort study. BMC Cardiovasc Disord. 2017;17:180.

27. Ogah OS., Stewart S. Onwujekwe OE., Falase AO., Adebayo SO., Olunuga T., et al., Economic burden of heart failure: investigating outpatient and inpatient costs in Abeokuta, S outhwest Nigeria.
PLoS One. 2014;9(11):e113032.

28. Schumock GT., Stubbings J., Wiest MD., Li EC., Suda KJ., Matusiak LM., et al., National trends in prescription drug expenditures and projections for 2018. Am J Health Syst Pharm. 2018;75(14):1023-1038.

29. Patented Medicine Proces Review Board. The drivers of prescription drug expenditures - a methodological report. 2013 [cited 2018 Agustus 1]. Available from: http://www.pmprbcepmb.gc.ca/CMFiles/NPDUIS/NPDUI S_Drivers_

Prescription_Drug_Expenditures_201312-13_EN.pdf.

30. Lee IH., Bloor K., Hewitt C., Maynard A. International experience in controlling pharmaceutical expenditure: influencing patients and providers and regulating industry - a systematic review. J Health Serv Res Policy. 2015;20(1):52-9.

31. Insull $\mathrm{W}$ Jr. The pathology of atherosclerosis: plaque development and plaque responses to medical treatment. Am J Med. 2009;122(1 Suppl):S3-S14. 